\title{
Textbook Development of Bank and Nonbank Financial Institution
}

\author{
Dita Eka Pertiwi Sirait ${ }^{1 *}$, Tri Effiyanti ${ }^{2}$, Irwansyah ${ }^{3}$ \\ ${ }^{1,2,3}$ Economic Education Study Program,Universitas Negeri Medan, Indonesia \\ *ditaekapertiwi@unimed.ac.id
}

\begin{abstract}
The purpose of this study is to find out (1) Design of bank textbook and nonbank financial institutions (2) Develop textbook of bank and non-bank financial institutions. The method used is the R \& D. The development procedure consists of 4-D (Four D Models) consist of define, design, develop and disseminate. Based on the results of expert validation on the developed textbooks obtained results for the content feasibility aspect of 4.0, the feasibility aspect of presentation amounted to 4.27 and the linguistic aspect of 4.37 with a feasible category.
\end{abstract}

Keywords: Textbook development, Bank and nonbank financial institution

\section{Introduction}

The subject of banks and non-bank financial institutions is one of the subjects that must be taken by students at the Faculty of Economics, State University of Medan. Other problems that are urgent in this course are: the occurrence of various policy changes related to bank financial institutions and non-bank financial institutions in Indonesia that cause the adjustment of teaching material in accordance with changes in regulations made by the government. The content of the material in textbooks of banks and financial institutions is also still a little that has made adjustments to changes in policy currently in force.

In accordance with Law Number 11 of 2011 concerning the Financial Services Authority (OJK) as of December 31, 2013 the bank's regulation and supervision is carried out by OJK. Thus BI will focus on controlling inflation and monetary stability. The transfer of BI's tasks to OJK has made major changes to the regulations relating to bank financial institutions and nonbank financial institutions, ranging from licensing, regulation of operational activities to the closure of financial institutions in Indonesia. So this will also have an impact on the content of the textbooks of bank courses and non-bank financial institutions. But in reality, there are only a few bank books and non-bank financial institutions whose contents have adjusted to these changes so that the teaching material becomes irrelevant to the actual conditions that actually occur. For example: material concerning Bank Indonesia, where one of its sub-materials is discussing the functions of Bank Indonesia. According to the old policy, the tasks of Bank Indonesia consisted of 3 (three), namely: 1) Determining and implementing monetary policy; 2) Arranging and Maintaining Smooth Payment Systems; 3) Manage and supervise banks. BI's third area of duty underwent a change after the transfer of the bank supervision function from Bank Indonesia to OJK. BI's third area of duty has also undergone a change, namely maintaining financial system stability in which in this case Bank Indonesia oversees banks macro prudential while OJK supervises banks micro prudential. 
The purpose of this study is to: determine the design of bank course books and non-bank financial institutions and develop bank course books and non-bank financial institutions.

\section{Theoretical Framework}

Textbooks are books that are used as textbooks in certain fields of study, which are standard books prepared by experts in their fields for instructional purposes and objectives, which are equipped with teaching facilities that are harmonious and easily understood by the users in schools and colleges so that they can support a teaching program [1]. Teaching book is one of the means of the success of the teaching and learning process [2]. Textbooks are a learning unit that contains information, discussion and evaluation. Textbooks arranged systematically will facilitate students in the material so that it supports the achievement of learning objectives. Therefore, textbooks must be arranged in a systematic, interesting, high readability aspect, easy to digest, and comply with applicable writing rules.

Important elements in the understanding of textbooks are as follows (1) textbooks are textbooks that are shown to students at certain levels. (2) Textbooks are always related to certain subjects. (3) Textbooks are standard books. (4) Textbooks are written for certain instructional purposes. (5) Textbooks are written to support a particular teaching program [3].

Function Textbooks provide facilities for independent learning activities, both about their substance and about their presenting. The use of textbooks is part of the book culture, which is a sign of advanced society. Viewed from the learning process, textbooks have an important role. If the purpose of learning is to make students have various competencies, the design of textbooks must include a number of principles that can be used to achieve this. The design of a number of questions is based on multiple representations.

Writing a textbook can be done with several techniques, in general there are 3 textbook writing techniques, namely: 1) Self-writing, the authors compile textbooks based on their own ideas and experiences. 2) Repacking information, the author does not compile textbooks themselves from scratch but rather utilizes books, textbooks, papers and other information that already exists. 3) Compile writings from various sources that are related and relevant to the theme [4]. Textbook authors can use one of the three textbook writing techniques above by prioritizing originality.

\section{Research Method}

This research is development type of research, the method of research and development $(\mathrm{R} \& \mathrm{D})$ is a research method used to research to produce certain products, and then test the effectiveness of these products [5]. This research develops new products in the form of developing learning devices based on blended learning in Bank Subjects and Non-Bank Financial Institutions. This research was conducted at the Economic Education Study Program, Medan State University, located at Jl. Willem Iskandar, Pasar V Medan.

Research subjects in this study were students of economic education study programs enrolled in the 2019/2020 school year. The class researcher chose was Class B Semester V.

The walkthrough technique is data validation which involves several experts to evaluate the product as a basis for revising the initial product. Data collection tools used in the form of 
validation sheets provided to experts. Validation sheets are given to experts in the form of a Likert scale.

The feasibility analysis of the textbook was obtained from the validation questionnaire by the experts of the research methodology. The data obtained is then tabulated for each aspect of the assessment and calculated using the formula as follows:

$$
\bar{x}=\frac{\sum x}{N}
$$

$\bar{x}=$ average total score

$\sum x=$ Amount of Score

$\mathrm{N}=$ Amount of indicator

Then the data is tabulated, the data obtained is then calculated the average total score of the assessment of each aspect of the assessment. The mean total score is then interpreted into a qualitative value based on the following criteria:

Table 1. Criteria of Validation Evaluation

\begin{tabular}{cccc} 
Value & $\begin{array}{l}\text { Score } \\
\text { Interval }\end{array}$ & Range & Criteria \\
\hline 5 & $\bar{x} \geq X+1,8 \mathrm{~S}$ & $4.21-$ & Very Feasible \\
& & 5.00 & \\
4 & $X+0,6 \mathrm{~S}$ & $3.41-$ & Feasible \\
& $<\bar{x} \leq X+1,8 \mathrm{~S}$ & 4.20 & \\
3 & $X-0,6 \mathrm{~S}$ & $2.61-$ & Rather feasible \\
& $<\bar{x} \leq X+0,6 \mathrm{~S}$ & 3.40 & \\
2 & $X-1,8 \mathrm{~S}$ & $1.81-$ & Not feasible \\
& $<\bar{x} \leq X+0,6 \mathrm{~S}$ & 2.60 & \\
1 & $\bar{x} \leq X-1,8 \mathrm{~S}$ & $0-1.80$ & Very not feasible \\
\hline
\end{tabular}

Information:

$\mathrm{X}=1 / 2$ (ideal maximum score + ideal minimum score)

$\mathrm{S}=1 / 6$ (ideal maximum score - minimum ideal score)

$\mathrm{x}^{-}=$The average value obtained

The assessment analysis for students of bank textbooks and non-bank financial institutions can be showed at this below table:

Table 2. Criteria of Student Response

\begin{tabular}{llll}
\hline Value & \multicolumn{1}{c}{ Interval Score } & Range & \multicolumn{1}{c}{ Criteria } \\
\hline 5 & $\bar{x} \geq X+1,8 \mathrm{~S}$ & $4.21-5.00$ & Very good \\
4 & $X+0,6 \mathrm{~S}<\bar{x} \leq X+1,8 \mathrm{~S}$ & $3.41-4.20$ & Good \\
3 & $X-0,6 \mathrm{~S}<\bar{x} \leq X+0,6 \mathrm{~S}$ & $2.61-3.40$ & Rather Good \\
2 & $X-1,8 \mathrm{~S}<\bar{x} \leq X+0,6 \mathrm{~S}$ & $1.81-2.60$ & Not good \\
1 & $\bar{x} \leq X-1,8 \mathrm{~S}$ & $0-1.80$ & Very not good \\
\hline
\end{tabular}




\section{Results and Discussion}

In developing this learning tool, the 4D development model consists of 4 stages, namely (1) define, (2) design, (3) develop, and (4) disseminate. Following is a description of each stage carried out:

a. Define

Define (definition) is the first stage conducted by researchers in the process of research and development of 4-D models. At this stage the researcher conducted the initial analysis, student Initial to Final Analysis [6,7,8]

1) From this identification, several problems were found, namely the content of textbooks that are not relevant to changes in government policies in force.

2) From the initial stages of the final problem was found, namely about students who were less eager to follow the learning. Then further observations were made on students about the reasons students were less interested in lecturing banks and non-bank financial institutions and what conditions they wanted in the lecture process. From the observation process it was found that students were less interested because conventional learning methods were boring for students and learning activities were less varied because they only used a face-to-face system (offline).

3) Task Analysis

There are 4 KKNI-based curriculum assignments at Universitas Negeri Medan, starting from the study material, subject matter, sub-topics and an outline of the contents of the subject. The curriculum used is KKNI, with the implementation of the KKNI-based curriculum at the Faculty of Economics, Universitas Negeri Medan there are six tasks that must be done by students including: Routine Tasks, Critical Book Report (CBR), Research Review / Journal Review, Mini Research, Engineering Ideas, Projects. In this Semester Learning Plan (RPS), guidelines for the six tasks are listed.

4) Material Analysis

Based on the analysis of the material in the syllabus of bank courses and non-bank financial institutions, 12 learning activities were developed as follows:

a) Learning Activity-1 (KB-1) discusses the definition and classification of Financial Institutions

b) Learning Activities-2 (KB-2) discusses Bank Indonesia

c) Learning Activity-3 (KB-3) discusses Commercial Banks

d) Learning Activities-4 (KB-4) discusses Bank Services

e) Learning Activity-5 (KB-5) discusses the Rural Credit Bank

f) Learning Activity-6 (KB-6) discusses Sharia Banks

g) Learning Activities-7 (KB-7) discusses Insurance

h) Learning Activity-8 (KB-8) discusses Leasing

i) Learning Activity-9 (KB-9) discusses the Pension Fund

j) Learning Activity-10 (KB-10) discusses PawnshopLearning Activities-11 (KB-11) discusses the Money Market and Capital Market

k) Learning Activities-12 (KB-12) discusses the Financial Services Authority

Based on the learning activities above the learning device is developed in accordance with the order of learning activities. 
b. Formulate learning experiences

Formulation of learning objectives based on the results of the initial initial analysis, student analysis and material analysis. The expected learning experience is students are able to explain the definition and classification of financial institutions, the objectives and tasks of Bank Indonesia, the basic concepts of commercial banks, types of bank services, basic concepts of Rural Credit Banks, Islamic Banks, insurance, leasing, pension funds, pawnshops, financial markets and capital markets and financial services authorities.

c. Design

The preparation of tests instruments in accordance with the preparation of lecture objectives that serve as a benchmark for the ability of students who refer to Bloom's taxonomy. The next step is to choose the format of the device and the initial design of the learning device. The format of the Semester Learning Plan (RPS) is guided by the format in force at the UNIMED Faculty of Economics. The format of the textbook is designed to consist of: learning outcomes, content material, questions (questions)

d. Develop

This phase aims to produce a revised set of learning tools based on expert input. The steps in this stage include a) expert validation, b) trials

\section{Expert Validation}

Expert validity of the textbooks was assessed based on 3 (three) aspects, namely: the content aspect, the musty presentation and linguistic aspects, the feasibility aspect consisted of 5 statements, the feasibility aspect of the presentation consisted of 11 statements, and the feasibility aspect of the language consisted of 12 statements. . The average score for eligibility in the content aspect is 4.0 , the mean score for the presentation aspect is 4.27 , and the average score for the linguistic aspect is 4.37 . This means that of the three aspects, the textbooks developed are included in the appropriate category for use

\section{Product Trial}

Limited product trials are conducted to see students' responses to the developed textbooks. Based on the results of the questionnaire responses that have been distributed to students, the average score of 4.04 is obtained in either category.

The average score of the total score of the textbook is 4.03 , which means that the validity assessment results from the validator team are in the proper criteria. Some suggestions from the Validator team for the textbooks that were developed are: 1) Every beginning of the chapter should begin with an explanation of learning achievements; 2) The material must be up to date, meaning that it must be in accordance with government policies that apply to bank financial institutions and non-bank financial institutions because government regulations on these institutions have experienced many changes since the transfer of the bank's supervisory function from BI to the Financial Services Authority (OJK) ; 3) At the end of each chapter there should be practice questions related to the material discussed in that chapter.

\section{Conclusion}

Based on the feasibility assessment of the validator team, the textbooks of bank courses and non-bank financial institutions are categorized as feasible with a mean score of 4.03 . 
Likewise, the assessment of student questionnaire responses was categorized well with the average total score of the response questionnaire of 4.04.

Based on the results and discussion of development research, learning tools for banks and non-bank financial institutions still have shortcomings and need to be corrected. For this reason, researchers give advice for conducting further research experimental research needs to be done to test the effectiveness of textbooks using the experimental class and the control class.

\section{References}

[1] Suhardjono. Menyusun Bahan Ajar. Malang: Universitas Brawijaya. (2008).

[2] Mintowati. Panduan Penulisan Buku Ajar. Depdikbud: Jakarta. (2003).

[3] Arifin, S. \& Kusrianto A. Sukses Menulis Buku Ajar \& Referensi. Grasindo. Jakarta. (2009).

[4] Bendor J. Self-editing and Revisions, Bahan Pelatihan Penulisan Artikel Ilmiah Internasional, DP2M: Jakarta. (2007).

[5] Sugiyono. Metodologi Penelitian Penddikan Pendekatan Kuantitatif, Kualitatif, dan $R \& D$. Bandung: Alfabeta. (2011).

[6] Poppy Kamalia Devi, et.al. Pengembangan Perangkat Pembelajaran. Bandung: P4TK IPA. (2009).

[7] Mudzakir, AS. Penulisan Buku Teks yang Berkualitas. Pustaka: Bandung. (2010).

[8] Sudjana, Nana. Dasar-dasar Proses Belajar Mengajar. Bandung. Sinar Baru Algensindo. (2005). 